\title{
Korean Peninsula Problem in the Light of the Latest Events
}

\author{
Kan Den Sik
}

Ph.D., Professor, Kyiv National Linguistic University, the Member of the National Unification Advisory Council under the President of South Korea (Kyiv, Ukraine)

E-mail: kme112000@yahoo.com

https://orcid.org/0000-0002-2191-4210

\begin{abstract}
Korea is still divided. However, the events of 2018 give a hope for solving one of the most acute problems of the world political life. The United States and Donald Trump also understand that sanctions are long-term processes, and resolving the issue by military force is also far from the best solution. Therefore, the summits of the RK - the DPRK, the United States - the DPRK should play a key role in unleashing the most difficult Korean problem. Before the RK - DPRK summit on April 27, 2018, and the United States - North Korea summit on 12th of May 2018, the unofficial consultations of the RKthe USA, the USA - Japan, the PRC - DPRK, DPRK - Russia were already finished. All the factors show the great importance of the previous and upcoming summits. Naturally, such important countries as China, Russia, Japan, which are the main actors of the Korean problem, play an important role in the upcoming high-level negotiation, as it was before.
\end{abstract}

The article describes the changes, which took place in 2018 on the Korean peninsula, ways and prospects for finding solution on the denuclearization and unification problems of Korea. The article examines the intensification reasons of both inter-Korean and the relations of other countries involved in the problem around the Korean Peninsula. The article also analyzes the preparation, conducting and outcome of the RK-DPRK, the USA-DPRK summits. There is underlined a main outcome of the summits as follows: the stabilization of peace and security on the Korean Peninsula, the intention to sign a peace treaty, the normalization of relations between the DPRK and the USA, the expression of North Korea's desire for complete, controlled and irreversible denuclearization. There is described the role of China in the processes relating to the Korean peninsula problems.

The conditions of the possibility of applying the experience of the unification of Korea to the resolution of modern problems of humanitarian development of Ukraine, namely, the consolidation of Ukrainian society and the development of social partnership practices are analyzed.

Keywords: summit; North Korean nuclear problem; nuclear state; regime; crisis; sanctions; Korean Peninsula denuclearization; Korean problem; peace treaty; inter-Korean relations; security guarantee; detente

Received: November 3, 2018; accepted: November 27, 2018

Ukrainian Policymaker, Volume 3, 2018: 51-57.

https://doi.org/10.29202/up/3/7

(C) Sik, Kan Den, 2018 
The Korean problem is still relevant today, despite the fact that it is going on for more than 70 years. The problem has not been solved yet and the actors involved in this problem are the same, but some of them have become stronger, others become weaker. There are a lot of changes in the main opposing Parties on the Korean Peninsula. However, the essence of the problem has remained the same, as before - Korea is the scene of the struggle of the powerful states. Therefore, even today, the Korean problem should be viewed through the prism of modern realities. This means that the unification is quite real with proper support and assistance from the countries involved in the Korean problem, and with the mutual understanding of the Koreans.

As it is known, one of the hottest spots in the world is the Korean Peninsula, due to the aggravation of the nuclear missile crisis. However, in last Kim Jong Un's New Year's greetings, the speech was different in content, structure, form and tone. The peculiarity was that the focus was on finding changes in inter-Korean relations by showing active gestures to reconciliation. Therefore, it was felt that the summit of RK - DPRK is inevitable, but no one expected it to happen so quickly.

If the RK - DPRK summit was somehow predicted, but no one expected the Trump and Kim Jong Un's meeting may happen so soon, considering the skirmishes that have been recently heard from both sides. Thus, the Olympic Games in Pyeongchang became a change point in the crisis on the Korean Peninsula. Of course, such a sharp metamorphosis in interKorean relations raises many questions, but one thing is clear that a new period in the Korean problem has begun.

The reason for such a metamorphosis will be discussed by experts and followers for a long time, but today it is clear that this is partly the result of North Korean leader, Kim Jong Un's, strategy and the policy of South Korean leader Moon Jae In striving to normalize the relationship, the lack of choice of a suitable embodiment for Trump, and of course, we cannot ignore the coincidence of the in world political life.

Of course, The North Korea got the strongest argument before the negotiations and showed that it has nuclear weapons and intercontinental missiles capable of reaching the American continent. It is not a secret for anyone that North Korea, at the cost of enormous effort and expense, despite all the sanctions, has achieved the goal, and therefore it may not conduct new tests in the near future. Many experts are surprised that, in spite of everything, the South and the North have set the preconditions and after their fulfillment, bilateral negotiations were possible, so the Parties agreed on holding the third summit.

South Korea demanded to stop the nuclear missile testing and denuclearization, while North Korea opposes holding joint military exercises of the Republic of Korea - the United States. In addition, North Korea insists on solving the problems by the Koreans themselves without outside intervention.

One of the reasons for warming relations is the concessions by South Korea, as well as the postponement of the USA-RK military training exercise, payment of expenses in the amount of $\$ 2,652,000$ for the Olympians of North Korea, the admission of Kim Jong Un's sister Kim Ye Chong and the meeting with the chairman of the DPRK Supreme Presidium - Kim Yong Nam. Thus, the Olympics in Pyeongchang became an arena for dialogue between the South and the North. It was not by chance that Kim Jong Un's sister Kim Ye Jeong came to the Olympics as a special envoy, who conveyed a message to Moon Jae In, expressing a desire to improve inter-Korean relations and an invitation. President Moon Jae In agreed to meet, providing the appropriate conditions. 
As it is known, President Moon Jae In sent a delegation, led by Special Envoy Jong Yi Yong, Head of the National Security Directorate under the President of the Republic of Korea, to Pyeongchang and on 5th of March during a meeting with Kim Jong Un, a wide range of issues were discussed.

As a result of the visit, they agreed to hold a third summit at the end of April 2018 at the Panmunjom border checkpoint. In addition, during the negotiations, an agreement was reached on the creation of a hotline between the leaders of the South and the North, on the creation of a preparatory group for the summit. According to the statement of Jong Yi Yong, the head of the delegation, Kim Jong Un expressed readiness for denuclearization in the case of providing the security guarantees to the regime by international community, and he expressed a desire to start a dialogue with the United States to establish bilateral relations and discuss the nuclear-missile problem. In addition, North Korea promised not to conduct nuclear testing at the time of the negotiations and expressed understanding about the South Korea's commitment to conduct the corresponding military exercises with the United States, postponed to a later date in connection with the Olympic Games in Pyeongchang. President Moon Jae In commended the results of the negotiations in Pyeongchang and sent round the head of the delegation, Jong Yong Yong, and the Director of the National Intelligence Service So Hoon to the United States for a consultation.

The delegation also visited China, Russia and Japan to inform them about the results of the negotiations and discuss prospects for inter-Korean relations. As a result of the visit, the delegation discussed the details of the meeting between Donald Trump and Kim Jong Un. The meeting of the leaders of the United States and the DPRK came as a surprise and the subject of hot discussion in modern politic world for several weeks. Politicians, scientists, journalists were concerned about whether they could cut the most complicated knots of the Korean problem, whether the current round of normalization would be sustainable, whether it would actually grow into the process of denuclearization of the Korean Peninsula and whether it would become one of the stages of peaceful reunification of Korea.

Of course, no one knows today when the next USA-DPRK summit will take place, but according to preliminary data, it will be in early 2019. As was expected, during the first summit on $12^{\text {th }}$ of June, 2018, they agreed on denuclearization as a whole, suspending nuclear missile tests and ending of USA-RK military exercises.

The entire world community is discussing the meeting of Trump and Kim Jong Un. What was the uniqueness of this meeting? Obviously, the uniqueness is as follows:

1. Until now, the United States and the DPRK have no diplomatic relations and practically have no cooperation.

2. The President of the United States never in the history met with the leader of North Korea. In addition, until recently, Trump and Kim Jong Un exchanged mutual attacks and did not express a desire to meet each other.

President Moon Jae In agreed to hold a summit, provided that a consensus at the meeting shall be reached on a key issue - the denuclearization of the Korean Peninsula. At the same time, Mr. Moon once again emphasized the importance of the USA-DPRK summit in solving the Korean problem.

The world community did not expect that Donald Trump would so quickly give consent to hold a summit with Kim Jong Un.

Andrei Lankov, a well-known Russian expert on North Korea and Korean studies, argues that the harsh sanctions policy and international isolation forced Kim Jong Un to make such a step. 
The opinion of another Russian scientist K. Asmolov is somewhat different. He believes that: "if the sanctions pressure has played a role, it is not a decisive one for sure." In addition, some Russian experts believed that the summit could not take place at all. The assumptions of Chinese Foreign Minister Wang Yi were justified, the negotiations were indeed very difficult, since Kim Jong Un would not simply give up on nuclear weapons, because it will not be easy to obtain the things he wants in return. The next surprise was three unofficial visits of Kim Jong Un to China, starting in March 2018.

Kim Jong Un's visit to China and the meeting with Xi Jing Ping show that Kim Jong Un's strategy is far from simple. By the beginning of the Pyeongchang Olympiad, North Korea received a comfortable position for negotiating with China, Republic of Korea and the United States. Therefore, in this strategy path, Kim Jong Un did not just visit China. It is clear that Kim Jong Un, who, after ascending the throne in 2011, never left North Korea's, but visited China three times, aiming to establish previous relations with the PRC, to get support from China and to develop tactics in the negotiation processes with the Republic of Korea and the United States.

It should be emphasized that after the PRC - the DPRK summit, a joint communiqué was not published. At previous meetings, official and unofficial in the amount of 9 times, there were no joint statements also.

It is also conceivable that an official or unofficial meeting with an ally - Russia is not excluded. Therefore, the meeting of the Foreign Affairs Ministers of the Russian Federation and the DPRK has already taken place. It is necessary to note and take into account the fact that the Republic of Korea and the United States embarked upon a joint military exercise, which was postponed in connection with the Olympiad. All these events suggest that the ice was broken, but it is still difficult to predict the results. One thing is clear: the year 2018 was hot and so far, it is not worthwhile to fall into euphoria, since the negotiations were and will not be easy due to the most complicated problems, which shall be solved. However, the most difficult issue, of course, is the problem of the denuclearization of the Korean Peninsula.

In our opinion, the problem should be solved as follows:

1. The conclusion of a peace treaty between the two Koreas. After all, there is only an armistice until now, signed by the United States, China and the DPRK.

2. The establishment of diplomatic relations between the DPRK - RK, the DPRK - the United States.

3. Developing of an effective way to provide a guarantee for the North Korean regime.

4. Re-examination of the existing system of an international treaty on the non-proliferation of nuclear weapons.

5. Development of a long-term strategy for the reunification of Korea, which will satisfy not only the DPRK and the RK, but also the PRC, the USA, the Russian Federation, Japan, that is, all the interested great powers involved in the Korean problem.

6. Development of Koreans consolidation strategy, not only for the people living in the RK and the DPRK, but also abroad.

Naturally, huge obstacles will arise on the way of resolving all these problems, however, no doubt, it is necessary to develop a clear plan and make every effort to reach a consensus in solving complex issues.

The Korean problem events of the first half of 2018 can be called swift-flowing, unpredictable and intense. Despite of many pessimistic statements, the DPRK-RK and the DPRK-USA summits were successfully finished. Of course, the key political events were the 
meetings of Kim Jong Un with Moon Jae In and Donald Trump. It is necessary to emphasize that the 2018 summits can become a new stage in the solution of the Korean problem and the beginning of a new era in the history of the Korean Peninsula. At the RK-DPRK summit, which took place on $27^{\text {th }}$ of April 2018, at the border area of Panmunjom, was signed a declaration on peace, prosperity and unification of the Korean Peninsula. The text of the declaration reflected following:

1. The problem of the denuclearization of the Korean Peninsula.

2. Termination of the war state and the peace establishment on the Korean Peninsula.

3. Opening of the channel for permanent communication between the South and the North.

4. Meetings of divided families.

5. Plans for developing of the inter-Korean relations.

In addition, a new summit in Pyongyang was agreed. Another important factor is the fact that the summit showed the desire of both countries to implement the agreements. Although many analysts are careful in further predictions, but consider it the beginning of an era of peace and prosperity in Korea.

Many Western experts are trying to analyze the results of the Trump - Kim Jong Un meetings (12 ${ }^{\text {th }}$ of June, 2018, Singapore), which ended with a rather extraordinary declaration of principles. Experts ask the question: did the United States get what they wanted from North Korea? Has the world become more stable after the summit, and is the situation on the Korean Peninsula more secure? There are plenty of expert opinions, but everyone notes the flexible strategy of the young Kim Jong Un. Of course, Kim Jong Un managed to do the things, which neither his grandfather Kim Il Sung, nor his father Kim Jong Il could do before. The only fact that he achieved a meeting on equal terms with the president of the great power is a major victory for the young leader. Kim Jong Un from an evil missile-man turned into a normal political leader. North Korea is a rogue state, and thanks to the Trump - Kim Jong Un summit, it received a symbolic international recognition, which was the main outcome of the game. So far, Kim Jong Un has not taken on any clear-cut commitments on the complete, controlled and irreversible nuclear disarmament, which Washington is trying to get in vain.

Jeffrey Lewis, North Korea's nuclear program expert at the Middlebury Institute for International Studies, believes that North Korea's recognition as a well-established country, who has the right to control it and the legitimacy of its "nuclear weapon" has succeeded. The British Financial Times writes that the United States made big concessions in return for North Korea's vague obligations. In a joint statement, the United States agreed to provide security assurances to North Korea in turn for a promise of denuclearization. Trump announced that the USA will suspend military exercises with South Korea. Meanwhile, Kim Jong Un did not provide details on how he would eliminate a nuclear program. North Korean media also consider him a great international politician. Thus, according to the media and the international political establishment, in the first set of the big game around the denuclearization of North Korea, the young Korean leader Kim Jong Un won. World media emphasize the great role of the president of the Republic of Korea, Moon Jae In. Without his active participation, the Trump - Kim Jong Un summit would hardly to be held.

Of course, China's leader Xi Jinping played a very important role, and China's support played an important role in determining the tactics and strategy of the meetings. The fact that the young Kim Jong Un before the summit visited Xi Jinping three times during three months for a consultation suggests that Pyongyang is in dire need of help and support of China. Thus, regardless of the results of the summit, Beijing was at the center of the negotiation process 
on the Korean issue. This means that all the Parts interested in normalizing of the relations with North Korea will be forced to apply to Beijing for assistance, since its influence on Pyongyang is more than obvious. The complete denuclearization of North Korea, which is the aim of the United States, Tokyo and Seoul, is possible only with Beijing's guarantee that Kim Jong Un will not share the same destiny as Muammar Gaddafi or Saddam Hussein, that his regime will not be overthrown. According to a number of experts, despite the fact that the relations between China and North Korea have reached a critically low point by the beginning of 2018, the current policy of the DPRK and the actions of its leaders are greatly influenced by China.

As it was reported by China's central television, the head of North Korea on his third visit to Beijing called China "the great friendly neighbor" of the DPRK, and the country's leader Xi Jinping "a great leader" accordingly. Mutual distrust and antipathy, that existed between Xi Jinping and Kim Jong Un, seemed not to exist. Mr. Kim invited Mr. Xi to celebrate the 70th anniversary of the DPRK foundation. In addition, according to the South China Morning Post, Mr. Xi promised China's economic assistance to North Korea at the meeting with Mr. Kim. Thus, the role of China, who is capable to guarantee the stability and security of North Korea, with its military-political protection and economic support, is very important. The results of Trump and Kim Jong Un meetings brought another benefit to China. As Jeremy Page writes in The Wall Street Journal, the lack of specific agreements on the way and time of denuclearization of the Korean Peninsula gives the opportunity to secure a direct role for China in the negotiations between Washington, Seoul and Pyongyang. Another successful outcome of the Singapore meeting for Beijing was Trump's words about his support for China's participation in the negotiations on signing a peace treaty, signifying the official end of the Korean War. In response, Xi Jinping proposed a four-sided structure of China, the DPRK, the USA and the RK to sign the peace document. He also stressed the impossibility to achieve complete, permanent and controlled denuclearization of North Korea without China.

However, today both the DPRK and the United States are not satisfied with the agreements progress reached at the Singapore Summit. In the case of North Korea's clear and decisive action on denuclearization, we can expect a weakening of sanctions against North Korea, which, first of all, would be beneficial for China. According to estimates of the South Korean Trade Agency KOTRA, China's share in North Korea's foreign trade was 93 \% in 2016, while Russia's share was only $1 \%$.

After the historic summits of China, South Korea launched a struggle for the "future North Korea". Despite the fact that the sanctions against the DPRK have not been canceled so far, a number of countries, such as Russia, Japan, are showing a very active interest in the North Korean project renewal. However, China and South Korea have a special interest in DPRK, where future economic benefits are closely intertwined with geopolitical plans. Seoul and Beijing have already developed plans for active penetration into North Korea through various investment and other cooperation projects, seeking to ensure that Pyongyang has chosen the development path for each country benefits. The interests of China and South Korea do not coincide, which will result in active competition on the territory of North Korea in the future. In addition, North Korea, judging by the approach, intends to use the contradiction in order to get the maximum benefit for itself.

In conclusion, it should be noted that all processes of the North Korea denuclearization are only the beginning of major changes; therefore, win-win meetings and consultations between 
China and North Korea, Republic of Korea and Japan, the USA and Japan, Russia and the DPRK, Russia and China continue today. In these negotiations, each country is looking for benefits for itself, but the following conclusions can be drawn:

1. Relief of tension on the Korean Peninsula is undisputed.

2. The real search for denuclearization has begun.

3. The desire of the Republic of Korea and the DPRK to fulfill the treaty on peaceful coexistence is evident.

In connection with the intensification of North Korean relations with China and South Korea, in order not to stay aloof from the events, it is necessary to develop a special strategy of relations, first of all with North Korea and secondly with the surrounding great powers.

The events of June-July 2018 on the Korean Peninsula should be accounted as an attempt to untie the knot of contradiction, which is linked with the international political processes at the global level. In addition, the 2018 summits analysis shows the following:

1. The complexity of the Korean problem and the impossibility of unification achieving in the near future.

2. Changing the balance of forces and the configuration of relations between the main actors involved in resolving the Korean problem.

3. The ambiguity of the approach of the United States, China, Russia and Japan to the Korean problem settlement.

The Korean problem at all stages of its development has its own peculiarity - a high activity and the influence of international factors, which affect the problem, and are used in different ways by the Republic of Korea and the DPRK.

Similar to the Korean problem, the reunification of the territory of Ukraine should be considered as a long-term process, the effectiveness of which largely depends on international factors, as well as the balance and configuration of relations between the main actors involved in resolving the Ukrainian problem. However, a significant difference in the situation in Ukraine is the necessity of resolving such internal problems as the fight against corruption (Bazaluk, 2016), overcoming the economic and political crisis.

\section{References}

Bazaluk, Oleg. Corruption in Ukraine: Rulers' Mentality and the Destiny of the Nation, Geophilosophy of Ukraine. Cambridge Scholars Publishing, 2016.

Jungang Ilbo. (2018.4.20). Mun Tethonneon "buk vandjonhan pihekcha” yidji phomeon [Moon President's willingness to free North Korea's complete nuclear cooperation]. [in Korean].

Thonil shide. (2018. 04). Kinmilhan hanmi kongdjo thonche pihekhwa indohal' ambakgwa yuinchek kanggu [Close USA-RK cooperation for denuclearization pushing and an incentive plan]. Vol. 138: 24-25.

Thonil shide. (2018. 04). "Yoksadjok tol'phadju” thonge tebudjedje vanha kide. [Expectation of easing of credit sanctions through "Historical breakthrough week"]. Vol. 138: 18.

Thonil shide. (2018.06). Vol.140: 11.

Thonil shide. (2018.07). Vol.141: 10. 